\title{
Age, serum 25-hydroxyvitamin D and vitamin D receptor (VDR) expression and function in peripheral blood mononuclear cells
}

\author{
Laura A. Coleman ${ }^{1,4, *}$, Margarita Mishina ${ }^{2, *}$, Mark Thompson ${ }^{3}$, Sarah M. Spencer ${ }^{2}$, \\ Adrian J. Reber ${ }^{3}$, William G. Davis ${ }^{3}$, Po-Yung Cheng ${ }^{3}$, Edward A. Belongia ${ }^{4}$, H. Keipp \\ Talbot $^{5}$, Maria E. Sundaram ${ }^{4,6}$, Marie R. Griffin ${ }^{5}$, David K. Shay ${ }^{3}$ and Suryaprakash \\ Sambhara ${ }^{3}$ \\ ${ }^{1}$ Abbott Nutrition, Columbus, $\mathrm{OH}$, USA \\ 2 Battelle, Columbus, OH, USA \\ ${ }^{3}$ U.S. Centers for Disease Control and Prevention, Atlanta, GA, USA \\ ${ }^{4}$ Marshfield Clinic, Marshfield, WI, USA \\ ${ }^{5}$ Vanderbilt University, Nashville, TN, USA \\ ${ }^{6}$ University of Minnesota School of Public Health, Minneapolis, MN, USA \\ * These authors have contributed equally to this work \\ Correspondence to: Laura A. Coleman, email: laura.coleman@abbott.com \\ Keywords: vitamin D, vitamin D receptor, la-hydroxylase, mRNA expression, PBMC, Gerotarget \\ Received: March 06, $2016 \quad$ Accepted: April 27, $2016 \quad$ Published: May 17, 2016
}

\section{ABSTRACT}

The relationship between age, vitamin D status, expression and functionality of the vitamin D receptor (VDR), and key genes in the vitamin D pathway in immune cells is unclear. We enrolled adults 50 to 69 years old ( 20 subjects) and 70+ ( 20 subjects) and measured: 1) 25(OH)D levels by liquid chromatography/mass spectrometry; and

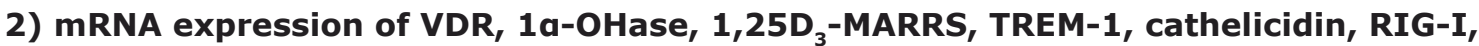
and interferon- $\beta$ by qRT-PCR. Mean serum 25(OH)D was $30 \pm 4 \mathrm{ng} / \mathrm{mL}$ and was not

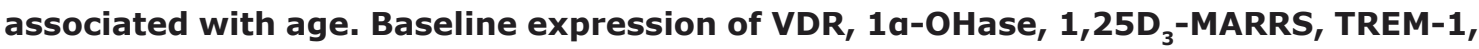
and RIG-I also did not differ by age; IFN- $\beta$ expression, however, was higher in the 70+ year old group. $25(\mathrm{OH}) \mathrm{D}_{3}-$ and $1,25(\mathrm{OH})_{2} \mathrm{D}_{3}$-induced VDR, TREM-1 and cathelicidin expression were similar between age groups, as was LPS-induced expression of VDR and of 1a-OHase. Ligand-induced $1,25 D_{3}$-MARRS expression was higher in subjects $\geq 70$ years. Serum 25(OH)D was inversely associated with LPS-stimulated VDR expression and with baseline or vitamin D-induced TREM-1 expression, adjusting for age, self-rated health, and functional status. In healthy adults $\geq \mathbf{5 0}$ years, the expression and functionality of the VDR, 1a-OHase and key vitamin D pathway genes were not consistently associated with age.

\section{INTRODUCTION}

Interest in the extra-skeletal effects of vitamin $\mathrm{D}$ has grown rapidly over the past thirty years with the identification of vitamin D receptors (VDRs) in various organ systems and cell types throughout the body $[1,2]$. The biologically active form of vitamin $\mathrm{D}, 1,25(\mathrm{OH})_{2} \mathrm{D}_{3}$, is produced by two hydroxylation reactions, the final one of which occurs mostly in the kidney via $1 \alpha$-hydroxylase (1 $\alpha$-OHase). Binding of the active form of vitamin D to its receptor leads to heterodimerization of the VDR with the retinoid-x receptor; the resulting complex binds to responsive elements in DNA and regulates the expression of several gene products involved in calcium and phosphorous absorption and metabolism, skeletal muscle function, bone metabolism, parathyroid function, and regulation of inflammation [2].

The effects of $1,25(\mathrm{OH})_{2} \mathrm{D}_{3}$ on the regulation of both the innate and adaptive immune systems are extensive, and are only beginning to be appreciated. The VDR has been found in activated CD4+ and CD8+ T cells, B cells, neutrophils, monocytes, macrophages, and dendritic cells [3]. Binding of vitamin D to VDR in macrophages, 
neutrophils and monocytes leads to the secretion of the antibacterial peptide, cathelicidin, which plays an important role in innate immune defenses via its ability to lyse bacteria [4]. Serum 25(OH)D levels have been associated with expression and functionality of certain toll like receptors (TLRs), especially those involved in viral responses [5]. Activation of innate immune receptors, such as TLR2, enhances the expression of VDR, $1 \alpha$-OHase and cathelicidin, suggesting a potential role for vitamin $\mathrm{D}$ in innate immune responses against bacterial pathogens [6]. Vitamin D has also been shown to inhibit $\mathrm{T}$ cell expansion and modulate the expression of cytokines with a Th2 bias [7]. Vitamin D inhibits differentiation and proliferation of B-lymphocytes, class switching and immunoglobulin secretion. Other immune effects that have been attributed to vitamin D include maturation of dendritic cells, downregulation of class II MHC expression and enhancement of antigen processing and presentation, leading to the induction of more tolerogenic cytokines such as IL-10 [3, 8]. This altered priming environment influences Th cell differentiation into Th2 $[9,10]$.

Potential clinical implications of the presence of VDR in immune cells include a possible role in autoimmunity, infectious diseases and cancer. For example, an association between vitamin D deficiency and the increased incidence of autoimmune diseases, namely, systemic lupus erythematosus, rheumatoid arthritis, multiple sclerosis, and inflammatory bowel disease in humans, and increased incidence of autoimmune disorders in animal models deficient in vitamin D function, have been reported and reviewed recently by Prietl et al. [11]. Vitamin D has been shown to inhibit the growth of mycobacterium tuberculosis in human macrophages through the secretion of antibacterial peptides [12]. Recent studies have also suggested that vitamin $\mathrm{D}$ has a beneficial effect in terms of patient survival in non-small cell lung cancer [13] and may act as a VDR agonist and therapeutic agent in EGFR mutant lung cancer [14].

Evidence has accumulated that $1,25(\mathrm{OH})_{2} \mathrm{D}_{3}$ regulates cell processes not only by traditional nuclear receptor-mediated transcriptional regulation (via VDR) but also by rapid signal transduction via the membrane receptor 1,25D - MARRS (Membrane Associated Rapid Response Steroid-binding) $[15,16]$. There is also evidence that VDR plays a role in non-transcriptional plasma membrane initiated signaling, and that $1,25 \mathrm{D}_{3}$-MARRSNFKB translocation into the nucleus may play a role in differentiation of the NB4 cell line along the monocyte/ macrophage lineage $[17,18]$. Data on the physiological role of membrane-initiated action of $1,25(\mathrm{OH})_{2} \mathrm{D}_{3}$ are limited, but mechanisms may involve $1,25(\mathrm{OH})_{2} \mathrm{D}_{3}$ -mediated signal transduction in cell proliferation as an early step in growth inhibition, likely followed by VDRmediated transcriptional regulation of proliferation [19]. Cross-talk between the two modes of vitamin D signaling may occur via targeted phosphorylation of critical proteins in the VDR-containing transcriptional complex [17, 20]. For example, antagonistic functions of $1,25 \mathrm{D}_{3}$-MARRS and VDR have been observed in breast cancer cells [18].

Altered physiological functions resulting in a dysregulated immune response to infectious diseases and enhanced susceptibility are a hallmark of aging $[21,22]$; this dysregulated immune status is referred to as immunosenescence [23, 24]. During aging, there is an increased incidence of colonization of bacteria and fungi on epithelial and mucosal surfaces, reactivation of latent and chronic infections and increased susceptibility to infectious diseases $[25,26]$. In addition, the immunogenicity and efficacy of preventive vaccines against bacterial and viral targets decline with aging [27, 28]. We and others have shown that the expression and function of innate immune receptors on macrophages and dendritic cells decline with aging [29-31]. Furthermore, we have also shown that reduced function of antigen presenting cells contributes to immune dysfunction in aging, which can be restored by either providing costimulation at the time of vaccination or formulating vaccines with adjuvants [31-34].

Since circulating levels of biologically inactive $25(\mathrm{OH}) \mathrm{D}$ need to be converted into the active form in order to have functional consequences, the expression and function of VDR, $1,25 \mathrm{D}_{3}$-MARRS as well as $1 \alpha$-OHase influence downstream effects. As information is limited on the expression and function of VDR, 1,25D - -MARRS and $1 \alpha$-OHasein aging, we investigated the association between age and the expression and function of VDR, $1,25 \mathrm{D}_{3}$-MARRS and $1 \alpha$-OHase in peripheral blood mononuclear cells (PBMCs) in healthy vitamin D replete adults $\geq 50$ years old. To determine the functionality of VDR, we measured the expression of human antibacterial peptide cathelicidin; triggering receptor expressed on myeloid cells 1 (TREM-1), a receptor of the innate immune system which is known to be induced by vitamin $\mathrm{D}$ [35]; retinoic acid inducible gene (RIG)-I and interferon (IFN)- $\beta$ genes, which play an important role in the response to viral challenges including influenza [36].

\section{RESULTS}

\section{Characteristics of the study participants}

Participant characteristics are shown in Table 1. The mean \pm SD age of subjects was $69.8 \pm 11.4$ years old; $55 \%$ were female. Participants were, by study design, community-dwelling and ambulatory. Age and health status were directly correlated among study participants (Table 2), however, most participants (27/40, 68\%) described themselves as being in very good or excellent overall health, and only $7 / 40$ (18\%) participants had elevated Vulnerable Elders Survey (VES-13) [37]scores 


\section{serum $25(\mathrm{OH}) \mathrm{D}$}

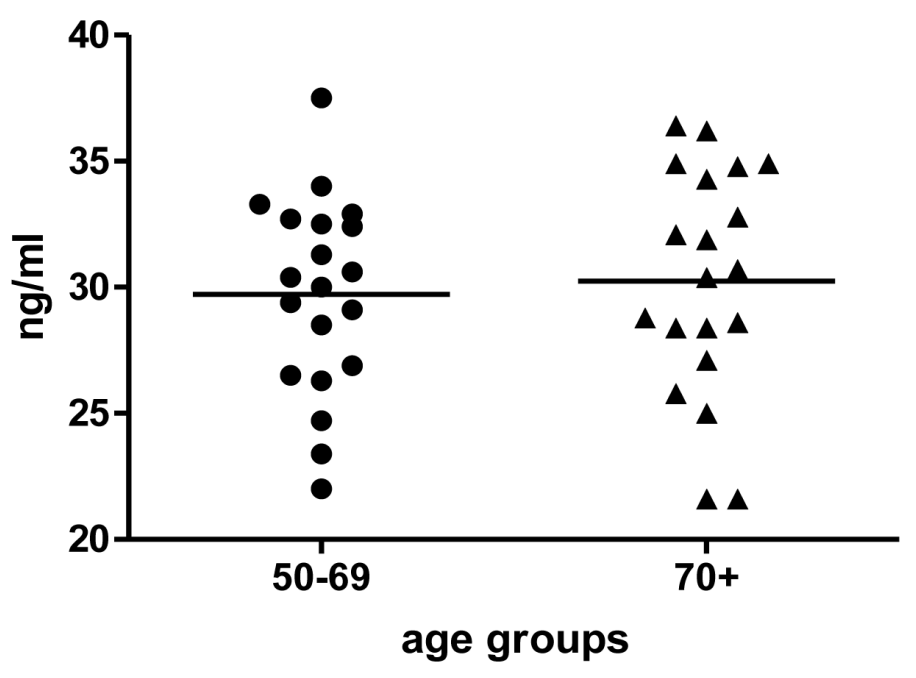

Figure 1: Serum 25(OH)D by age group. The participants were chosen with serum 25(OH)D levels in the sufficient range (mean \pm $\mathrm{SD}, 30.0 \pm 4.1 \mathrm{ng} / \mathrm{mL})$ [48]. Serum 25(OH)D was similar for both age groups. The mean of the values within age groups is represented by the horizontal line.
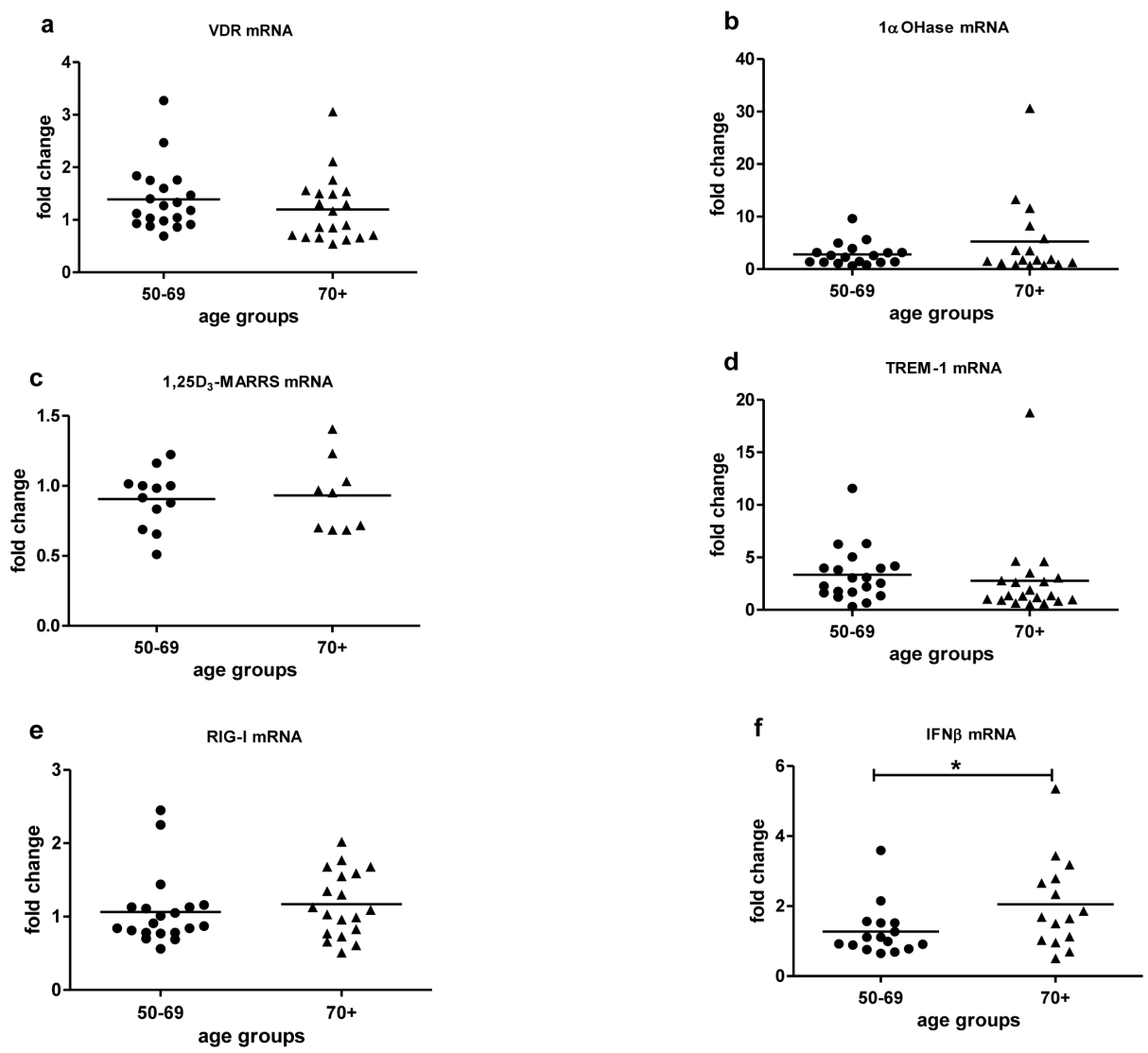

Figure 2: Baseline mRNA expression by age. VDR a., $1 \alpha$-OHase b., $1,25 \mathrm{D}_{3}$-MARRS c., TREM- 1 d., RIG-I e., IFN- $\beta$ f. mRNA expression by age group was measured in untreated PBMCs and compared to expression in a calibrator sample (untreated random PBMCs). Gene expression was assessed by RT-qPCR.All assays were done in duplicate and expression was normalized to $\beta$-actin. The relative amount of target gene in each sample was estimated using the $2^{-\Delta \Delta C T}$ method as described elsewhere [49]. The mean of the values is represented by the horizontal line. Statistical analysis was performed by Student's test $(* p<0.05)$. 
Table 1: Participant characteristics

\begin{tabular}{|l|l|l|l|l|l|}
\hline Characteristics & Scale & $\begin{array}{l}\text { Full Sample }(\boldsymbol{n} \\
=\mathbf{4 0})\end{array}$ & $\begin{array}{l}\text { Age 50-69 }(\boldsymbol{n}= \\
\mathbf{2 0})\end{array}$ & Age 70+ $(\boldsymbol{n}=\mathbf{2 0})$ & $\begin{array}{l}\boldsymbol{P} \text {-value } \\
\text { between } \\
\text { groups3 }\end{array}$ \\
\hline Age & Years & $69.8(11.4)$ & $59.4(4.5)$ & $80.1(4.8)$ & $<0.001$ \\
\hline Female sex & $\mathrm{N}(\mathrm{col} \%)$ & $22(55)$ & $10(50)$ & $12(60)$ & NS \\
\hline BMI & $\mathrm{kg} / \mathrm{m}^{2}$ & $26.8(5.0)$ & $26.4(5.2)$ & $27.2(5.0)$ & $\mathrm{NS}$ \\
\hline Self-rated health & $1=$ poor to 5=excellent & $3.9(0.9)$ & $4.2(0.9)$ & $3.7(0.9)$ & $\mathrm{NS}$ \\
\hline VES-13 & $1.2(1.7)$ & $0.3(0.8)$ & $2.1(1.9)$ & $<0.001$ \\
\hline $\begin{array}{l}\text { Number difficult daily } \\
\text { activities from VES-13 }\end{array}$ & $\begin{array}{l}\text { Of 11 activities of daily } \\
\text { living, number difficult to } \\
\text { do (0-6) }\end{array}$ & $1.2(1.7)$ & $0.7(1.3)$ & $1.8(1.9)$ & $<0.05$ \\
\hline Serum 25(OH)D & ng/mL & $30(4.1)$ & $29.7(3.9)$ & $30.2(4.5)$ & NS \\
\hline
\end{tabular}

${ }^{1}$ Mean (SD) unless otherwise noted

${ }^{2}$ Vulnerable Elders Survey

${ }^{3}$ Age-group comparisons were made using Student's T-test, with the exception of Chi-square for comparison of male and female participants.
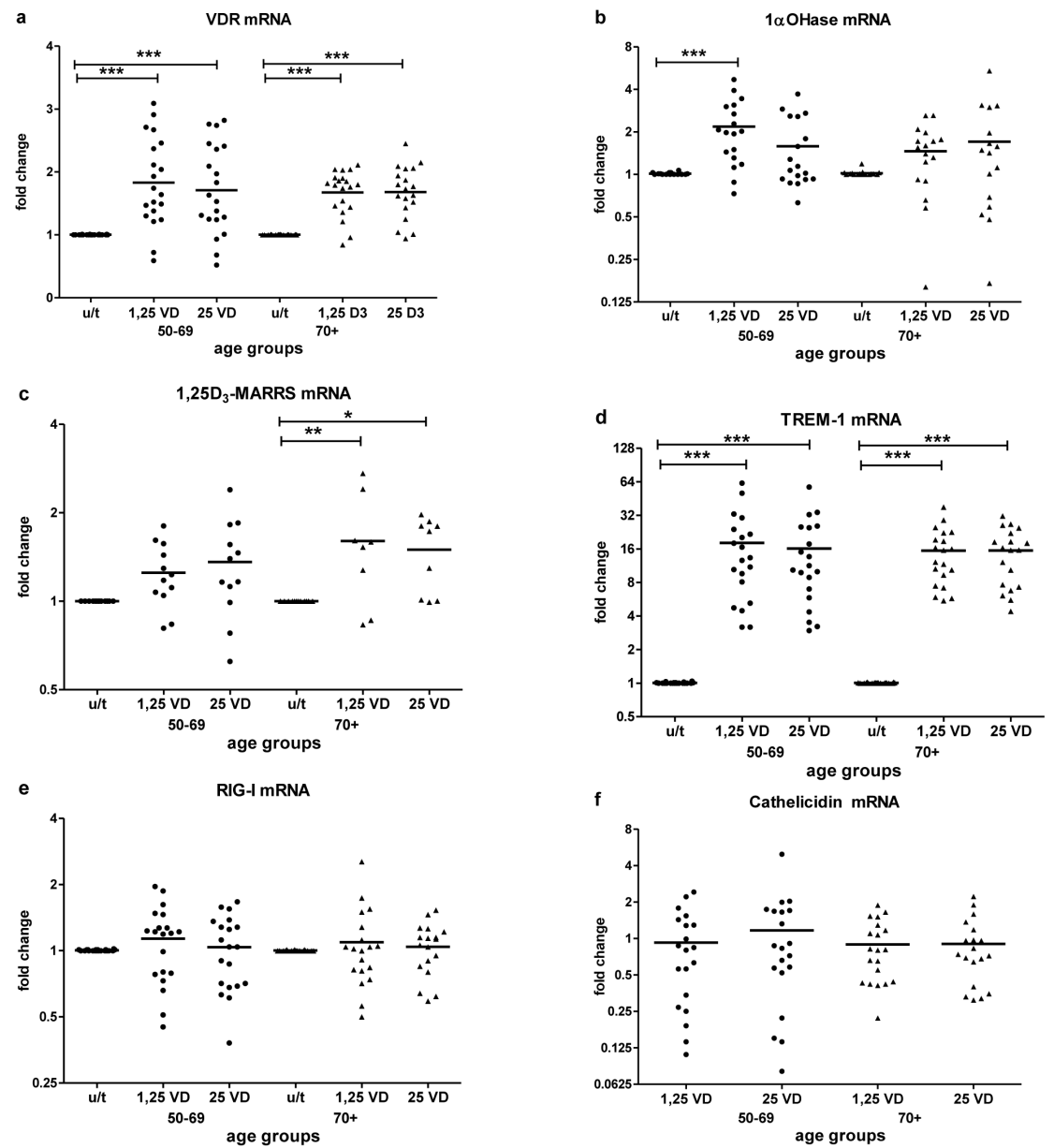

Figure 3: Vitamin D-induced mRNA expression by age. The response to vitamin D stimulation by age group was determined by fold change in VDR a., 1aOHase b., 1,25D -MARRS c.,TREM-1 d. and RIG-I e. mRNA expression after in vitro treatment of PBMCs with active $1,25(\mathrm{OH})_{2} \mathrm{D}_{3}$ or inactive $25(\mathrm{OH}) \mathrm{D}_{3}$ compared to untreated PBMCs. Cathelicidin $\mathbf{f}$. mRNA expression was measured in vitamin D-treated samples and compared to expression in a calibrator sample (vitamin D treated random PBMCs) due to Cathelicidin mRNA at baseline was below the limit of detection. Gene expression was assessed by RT-qPCR. All assays were done in duplicate and expression was normalized to $\beta$-actin. The relative amount of target gene in each sample was estimated using the $2^{-\Delta \Delta C \mathrm{CT}}$ method as described elsewhere [49]. The mean of the values is represented by the horizontal line.u/t: untreated PBMCs; 1,25 VD: PBMCs treated with $1,25(\mathrm{OH})_{2} \mathrm{D}_{3} ; 25 \mathrm{VD}$ : PBMCs treated with $25(\mathrm{OH}) \mathrm{D}_{3}$ Statistical analysis was performed by ANOVA $\left({ }^{*} p<0.05^{* *}, p<0.01,{ }^{* * *} p<0.001\right)$. 
Table 2: Correlations between age and other characteristics and gene expression

\begin{tabular}{|c|c|}
\hline Characteristics/gene expression & \begin{tabular}{|l}
$\begin{array}{l}\text { Correlation (r ) with } \\
\text { age (years) }\end{array}$ \\
\end{tabular} \\
\hline Female sex & 0.18 \\
\hline VES-13 score & $0.66^{*}$ \\
\hline Self-rated health & $-0.36^{*}$ \\
\hline Serum 25(OH)D & -0.06 \\
\hline \multicolumn{2}{|l|}{ VDR } \\
\hline Baseline & -0.23 \\
\hline 1,25(OH)2D3-induced & -0.20 \\
\hline 25(OH)D3-induced & -0.15 \\
\hline LPS-induced & -0.01 \\
\hline \multicolumn{2}{|l|}{$1 \alpha$-OHase } \\
\hline Baseline & 0.28 \\
\hline 1,25(OH)2D3-induced & 0.04 \\
\hline 25(OH)D3-induced & 0.20 \\
\hline LPS-induced & 0.15 \\
\hline \multicolumn{2}{|l|}{ TREM-1 } \\
\hline Baseline & -0.17 \\
\hline 1,25(OH)2D3-induced & -0.18 \\
\hline 25(OH)D3-induced & -0.22 \\
\hline LPS-induced & -0.14 \\
\hline \multicolumn{2}{|l|}{ IFN- $\beta$} \\
\hline Baseline & $0.32 *$ \\
\hline LPS-induced & $0.45^{*}$ \\
\hline \multicolumn{2}{|l|}{ 1,25D3-MARRS ${ }^{1}$} \\
\hline Baseline & \begin{tabular}{|l|}
-0.14 \\
\end{tabular} \\
\hline 1,25(OH)2D3-induced & 0.26 \\
\hline 25(OH)D3-induced & 0.19 \\
\hline LPS-induced & $0.46^{*}$ \\
\hline
\end{tabular}

$* p<0.05$

${ }^{1}$ Assays completed on 21 of 40 subjects due to limited RNA.

( $\geq 3$ ) indicative of functional decline. As expected, participants aged $\geq 70$ years had modestly higher VES-13 scores. Serum vitamin D levels were similar among those aged $50-69$ and $\geq 70$ years $(29.7 \pm 3.9$ and $30.2 \pm 4.5 \mathrm{ng} / \mathrm{mL}$, respectively) (Figure 1).

\section{Baseline expression and functionality of VDR and 1o-OHase}

Baseline expression of key vitamin D pathway genes, VDR (Figure 2a), 1 $\alpha$-OHase (Figure 2b) and $1,25 \mathrm{D}_{3}$-MARRS (Figure 2c), and of TREM-1 (Figure 2d) and RIG-I (Figure 2e) did not differ by age group (Table 2). Cathelicidin mRNA at baseline was below the limit of detection for all age groups. IFN- $\beta$ mRNA expression was higher in subjects $\geq 70 v s$. $<70$ years $(p<0.05)$ (Figure 2f). In vitro exposure of PBMCs to either form of vitamin $\mathrm{D}-1,25(\mathrm{OH})_{2} \mathrm{D}_{3}$ (the biologically active ligand) or $25(\mathrm{OH}) \mathrm{D}_{3}$ - induced VDR similarly in both age groups (Figure 3a). 1 $\alpha$-OHase was induced by vitamin D; this finding reached statistical significance only in the case of $1,25(\mathrm{OH})_{2} \mathrm{D}_{3}$ treatment for subjects $<70$ years $(\mathrm{p} \leq 0.001)$ (Figure 3b). 1,25D $\mathrm{D}_{3}$-MARRS was induced by both vitamin D metabolites, but only reached significance for subjects $\geq 70$ years (Figure 3c). As expected, either form of vitamin D induced TREM-1 $(p<0.001)$ (Figure 3d) and cathelicidin expression (Figure 3f). The levels of induction were similar for both age groups (Table 2). Neither RIG-I (Figure 3e) nor IFN- $\beta$ (data not shown)was affected by treatment of cells with the vitamin D metabolites.

Assessment of VDR, $1 \alpha$-OHase and $1,25 \mathrm{D}_{3}$ MARRS responsiveness to an immune stimulus was done by treating PBMCs with LPS. LPS upregulated the expression of VDR $(p<0.01)$ (Figure $4 a)$ and $1 \alpha$-OHase $(p<0.05)$ (Figure $4 \mathrm{~b})$ in both age groups equally. $1,25 \mathrm{D}_{3}$ MARRS was upregulated by LPS slightly for group 70+, not reaching statistical significance (Figure 4c); 
Table 3: Association between serum 25(OH)D level and gene expression

\begin{tabular}{|c|c|c|}
\hline \multirow[t]{2}{*}{ Gene expression } & \multicolumn{2}{|c|}{$\begin{array}{l}\text { Associations (Beta Coefficients) with } \\
\text { Serum } 25(\mathrm{OH}) \mathrm{D}^{1}\end{array}$} \\
\hline & Unadjusted & \begin{tabular}{|l|} 
Adjusted \\
\end{tabular} \\
\hline \multicolumn{3}{|l|}{ VDR } \\
\hline Baseline & -0.07 & -0.09 \\
\hline $1,25(\mathrm{OH})_{2} \mathrm{D}_{3}$-induced & -0.29 & -0.31 \\
\hline $25(\mathrm{OH}) \mathrm{D}_{3}$-induced & -0.23 & -0.25 \\
\hline LPS-induced & $-0.32 *$ & $-0.33^{*}$ \\
\hline \multicolumn{3}{|l|}{$1 \alpha-$ OHase $^{2}$} \\
\hline Baseline & -0.04 & -0.06 \\
\hline $1,25(\mathrm{OH})_{2} \mathrm{D}_{3}$-induced & -0.25 & -0.23 \\
\hline $25(\mathrm{OH}) \mathrm{D}_{3}$-induced & -0.09 & -0.07 \\
\hline LPS-induced & -0.20 & -0.20 \\
\hline \multicolumn{3}{|l|}{ TREM-1 } \\
\hline Baseline & $-0.31 *$ & $-0.31 *$ \\
\hline $1,25(\mathrm{OH})_{2} \mathrm{D}_{3}$-induced & $-0.38^{*}$ & $-0.40 *$ \\
\hline $25(\mathrm{OH}) \mathrm{D}_{3}$-induced & $-0.33 *$ & $-0.35 *$ \\
\hline LPS-induced & $-0.39 *$ & $-0.41^{*}$ \\
\hline \multicolumn{3}{|l|}{ IFN- $\beta^{3}$} \\
\hline Baseline & 0.07 & 0.06 \\
\hline $1,25(\mathrm{OH})_{2} \mathrm{D}_{3}$-induced & -0.09 & -0.08 \\
\hline $25(\mathrm{OH}) \mathrm{D}_{3}$-induced & -0.08 & -0.10 \\
\hline LPS-induced & -0.13 & -0.12 \\
\hline \multicolumn{3}{|l|}{$1,25 \mathrm{D}_{3}-$ MARRS $^{4}$} \\
\hline Baseline & -0.06 & -0.08 \\
\hline $1,25(\mathrm{OH})_{2} \mathrm{D}_{3}$-induced & -0.22 & -0.36 \\
\hline $25(\mathrm{OH}) \mathrm{D}_{3}$-induced & -0.28 & -0.29 \\
\hline LPS-induced & -0.18 & -0.25 \\
\hline
\end{tabular}

$* \mathrm{p}<0.05$

${ }^{1}$ Unadjusted associations are standardized Betas (correlations); adjusted for age, self-rated health, and sum of difficult daily activities from VES-13.

${ }^{2}$ For stimulated conditions, assay completed on 35 of 40 subjects due to limited RNA.

${ }^{3}$ Assay completed on 31 of 40 subjects due to limited RNA.

${ }^{4}$ Assays completed on 21 of 40 subjects due to limited RNA.

LPS-induced $1,25 \mathrm{D}_{3}$-MARRS expression was positively associated with age (Table 2).

\section{Correlation of gene expression and serum vitamin D concentration}

We analyzed the association between VDR pathway/downstream vitamin $\mathrm{D}$ target genes and serum vitamin D concentrations (Table 3). LPS-stimulated VDR expression $(r=-0.33)$ and baseline TREM-1 $(r=-0.31)$ and vitamin D-stimulated $(r=-0.40)$ TREM-1 expression were inversely associated with serum $25(\mathrm{OH}) \mathrm{D}$, adjusting for age, self-rated health, and functional status $(p<$ $0.05)$ (Table 3). Serum 25(OH)D concentration was not associated with $1,25 \mathrm{D}_{3}$-MARRS or $1 \alpha$-OHase expression, or with IFN- $\beta$ expression (Table 3 ).

\section{DISCUSSION}

In this study of healthy, community-dwelling, vitamin D-replete adults 50 years and older, baseline level and functionality (responsiveness to vitamin D and LPS) of the VDR and $1 \alpha-$ OHase were not associated with age. LPS-induced $1,25 \mathrm{D}_{3}$-MARRS expression was positively associated with age. Serum $25(\mathrm{OH}) \mathrm{D}$ was within the normal range ( $30 \pm 4 \mathrm{ng} / \mathrm{mL}$ ) by study design, and there was an inverse association of LPS-induced VDR mRNA level and serum vitamin $\mathrm{D}$. The downstream target gene TREM-1 (baseline) and vitamin D-induced mRNA expression were also inversely associated with serum vitamin $\mathrm{D}$. These results suggest differential regulation of the vitamin $\mathrm{D}$ pathway in immune cells by serum vitamin D. 
Bischoff-Ferrari et al. reported that older age was associated with decreased VDR protein expression in human skeletal muscle tissue, independent of serum $25(\mathrm{OH}) \mathrm{D}$ levels [38]. The disagreement with the current study may be because regulation of expression is tissuespecific. Moreover, their study included adults ranging from age 24 to 91 years old, contrary to our study which only included adults 50 years and older. Also, our older adult population was generally healthy; by study design, all subjects were free-living. Thus, this group of subjects likely does not represent an elderly population with advanced immune senescence and results cannot be generalized to all elderly individuals. Indeed, the participants in the current study may represent individuals with a longer "health span" rather than only a longer "life span" [39]. In addition, Bischoff-Ferrari et al. measured protein levels, while our study focused on mRNA expression. Post-transcriptional regulation of expression can be affected by aging. There have not been any reports on $1 \alpha$-OHase and $1,25 \mathrm{D}_{3}$-MARRS expression being altered with aging.

In the present study, the expression of IFN- $\beta$, an important antiviral regulator of immunity, was higher in subjects over 80 years. This finding is in agreement with the previous reports that low-level chronic inflammation, or "inflammaging", is commonly observed in older populations $[40,41]$. IFN- $\beta$ is regulated by multiple signaling pathways, with the RIG-I pathway being one of them [42]. However, we observed no regulation of IFN- $\beta /$ RIG-I mRNA expression by vitamin $D$ treatment of immune cells or association of IFN- $\beta$ expression with circulating 25(OH)D.

Besides cellular VDR content and active ligand accessibility to the VDR, the biological VDR-mediated response to $1,25(\mathrm{OH})_{2} \mathrm{D}_{3}$ is also influenced by availability and activation status of nuclear co-regulators [43].
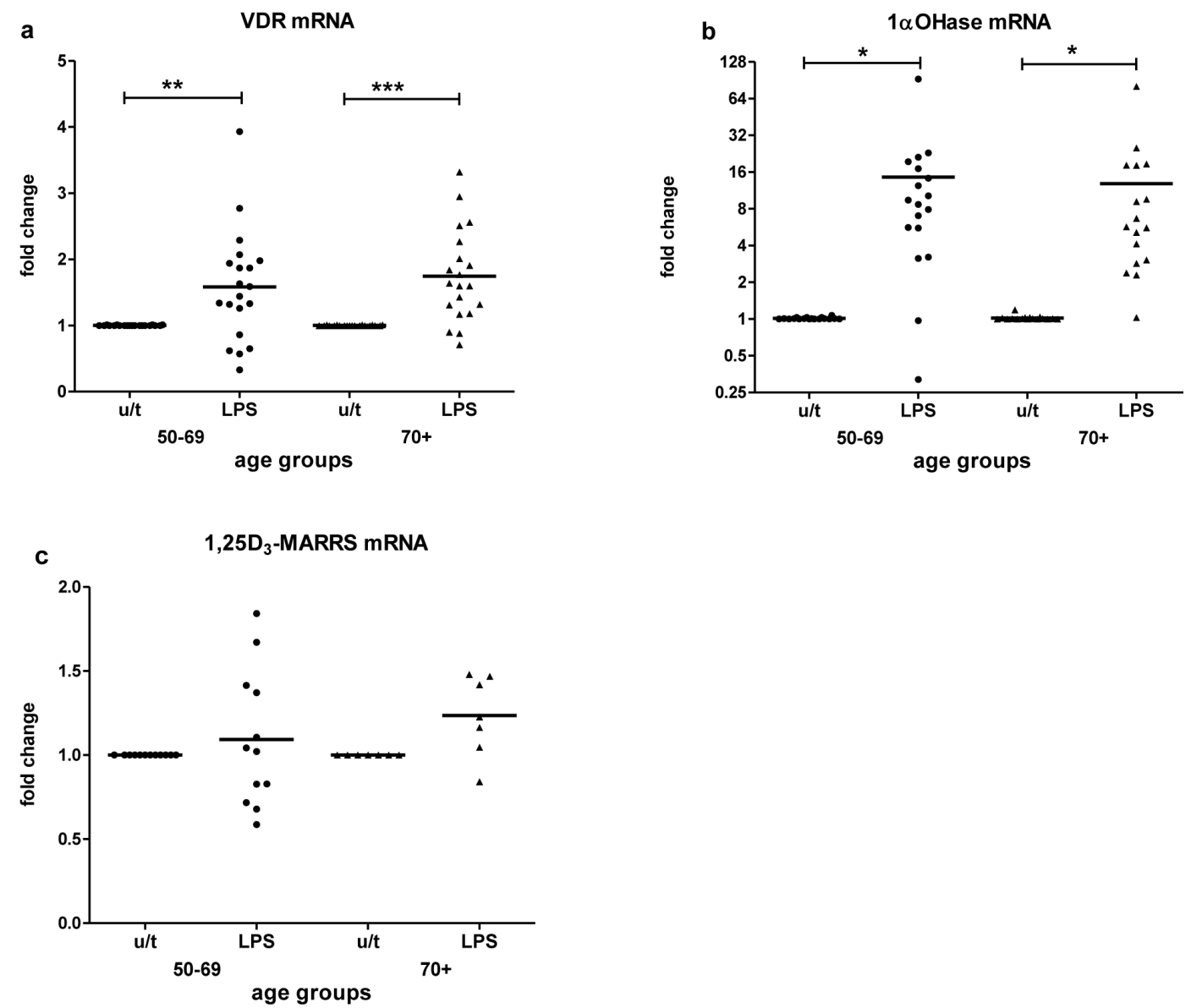

Figure 4: LPS-stimulated mRNA expression by age. The response to LPS stimulation by age group was determined by fold change in VDR a., $1 \alpha$-OHase b. and 1,25D -MARRS c. mRNA expression after in vitro treatment of PBMCs compared to untreated PBMCs. Gene expression was assessed by RT-qPCR.All assays were done in duplicate and expression was normalized to $\beta$-actin. The relative amount of target gene in each sample was estimated using the $2^{-\Delta \Delta C \mathrm{CT}}$ method as described elsewhere [49]. The mean of the values is represented by the horizontal line. $\mathrm{u} / \mathrm{t}$ : untreated PBMCs; LPS: PBMCs treated with LPS. Statistical analysis was performed by ANOVA $(* p<0.05, * * p<$ $0.01, * * * p<0.001)$. 
Information on the role of $1,25 \mathrm{D}_{3}$-MARRS in immune responses, including cross-talk with the VDR, is very limited, and all components of the vitamin D pathway in immune cells can be affected by age. Future studies are needed in a population with a range of vitamin $\mathrm{D}$ status and age, to address how vitamin D level and aging affect the VDR- 1,25D-MARRS pathways in immune cells, both independently and synergistically.

\section{MATERIALS AND METHODS}

\section{Study participants and data collection}

As part of a larger study designed to investigate immune response to influenza vaccination, forty adults $\geq 50$ years old (mean \pm SD $69.8 \pm 11.4$ years) were enrolled at two sites, Vanderbilt University Medical Center (Nashville, TN) and Marshfield Clinic Research Foundation (Marshfield, WI), during the months of September through October 2008. The details of recruitment, data collection and blood collection/ processing have been described in detail elsewhere [44, 45]. To describe the risk of functional decline or death, participants completed the 13-item VES-13 [37], which results in a 10-point score with scores $\geq 3$ associated with higher risk of death or functional decline. This measure presents 11 activities of daily living; we report the number ( 0 to 6 or more) described as difficult on average to complete (e.g., ability to stoop or crouch, to lift or carry heavy objects, perform heavy housework). The difficulty of 6 of these activities were rated as "no difficulty" $(0)$ or "a little difficult" (1) to "unable to do" (4) and summed to form a difficulty score of 0 to 18 or higher. We also report on the participant's self-rated overall health status $(1=$ poor to $5=$ excellent $)[46,47]$.

Blood samples from 20 participants in each of the following age groups were analyzed: $50-69$ and $\geq 70$ years. In order to minimize the influence of circulating $25(\mathrm{OH})$ $\mathrm{D}$ concentration on the vitamin $\mathrm{D}$ pathways in cells of the immune system, the participants chosen for inclusion in the present study had serum $25(\mathrm{OH}) \mathrm{D}$ levels of 20-40 $\mathrm{ng} / \mathrm{mL}$ (based on the Institute of Medicine's definition of sufficiency) (Figure 1) [48]. Study procedures, informed consent documents and data collection forms were reviewed and approved by Institutional Review Boards at each of the study sites and Centers for Disease Control and Prevention.

\section{Laboratory methods}

Serum 25(OH)Dwas measured by liquid chromatography/mass spectrometry [44]. 1×106 PBMCs were stimulated with $200 \mathrm{ng} / \mathrm{mL}$ of $1,25(\mathrm{OH})_{2} \mathrm{D}_{3}$ or $25(\mathrm{OH}) \mathrm{D}_{3}$ or $100 \mathrm{ng} / \mathrm{mL}$ of LPS obtained from Sigma
(St. Louis, MO), for 20 hrs. mRNA was purified using RNeasy mini kit (QIAGEN, Valencia, CA). Expression of

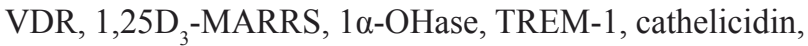
RIG-I, and IFN- $\beta$ was measured by Real-Time quantitative Reverse Transcription Polymerase Chain Reaction (qRTPCR) with SuperScript III Platinum SYBR Green OneStep qRT-PCR- kit ( Life Technologies, Grand Island, NY) or with Transcriptor Reverse Transcriptase ( Roche, Indianapolis, IN) followed by SYBR Green JumpStart Taq ReadyMix (Sigma, St. Louis, MO ) with gene-specific primers (Table S1) using real-time detection instrument Mx3000P (Stratagene, Santa Clara, CA). All assays were done in duplicate and expression was normalized to $\beta$-actin. The relative amount of target gene in each sample was estimated using the $2^{-\Delta \Delta \mathrm{CT}}$ method as described elsewhere [49].

\section{Statistical analysis}

Chi-square tests and Student's $T$-tests were used to compare the characteristics of participants by age group. We used linear regression models to describe the association between serum $25(\mathrm{OH}) \mathrm{D}$ levels and gene expression. Given that all study variables are likely associated with age and underlying health and functional status, we present standardized Beta coefficients adjusted for age, self-rated health status, and functional status (i.e., the sum of difficult daily activities).

\section{Abbreviations}

The following abbreviations are used in this manuscript:

25-hydroxyvitamin D: 25(OH)D

VDR: vitamin D receptor

1,25D $\mathrm{D}_{3}$-MARRS: membrane associated, rapid response, steroid-binding receptor protein

PBMC: peripheral blood mononuclear cells

$1,25(\mathrm{OH})_{2} \mathrm{D}_{3}: 1,25$ dihydroxyvitamin $\mathrm{D}_{3}$

$1 \alpha$-OHase: 1 alpha hydroxylase

TLR: toll like receptor

TREM-1: triggering receptor expressed on myeloid cells

RIG-I: retinoic acid inducible gene I

IFN- $\beta$ : interferon beta

VES-13: vulnerable elders survey

qRT-PCR: quantitative reverse transcription polymerase chain reaction

LPS: lipopolysaccharide

\section{ACKNOWLEDGMENTS}

This study was funded by the Centers for Disease Control and Prevention. The findings and conclusions in this report are those of the authors and do not necessarily 
represent the views of the Centers for Disease Control and Prevention.

\section{CONFLICTS OF INTEREST}

The authors, MM, MT, SMS, AJR, WGD, P-YC, EAB, DKS and SS declare no conflict of interest. HKT has received research funding from Sanofi Pasteur, MedImmune, and Gilead; and she serves on Advisory Boards for Teva Pharmaceuticals and MedImmune. MES has received research funding from MedImmune. MRG receives research funding from MedImmune. LAC is an employee of Abbott Nutrition.

\section{Authors' contributions}

MM, AJR, and WGD performed the experiments, collected the data and analyzed them. MT and P-YC performed statistical analyses. SS, EAB, HKT, MES, MRG, DKS, LAC and SS, conceived, planned, coordinated and conducted the study. LAC, MT, MM and SS have written the manuscript.

\section{REFERENCES}

1. Uitterlinden AG, Fang Y, VanMeurs JB, Pols HA and VanLeeuwen JP. Genetics and biology of vitamin D receptor polymorphisms. Gene. 2004; 338:143-156.

2. Wolden-Kirk H, Gysemans C, Verstuyf A and Mathieu C. Extraskeletal effects of vitamin D. Endocrinol Metab Clin N Am. 2012; 41:571-594.

3. Baeke F, Takiishi T, Kork H, Gysemans C and Mathieu C. Vitamin D: modulator of the immune system. Curr Opin Pharmacol. 2010; 10:482-496.

4. Hewison M. Vitamin D and immune function: an overview. Proc Nutr Soc. 2011; 71:50-61.

5. Alvarez-Rodriguez L, Lopez-Hoyos M, Garcia-Unzueta M, Amado JA, Cacho PM and Martinez-Taboada VM. Age and low levels of circulating vitamin D are associated with impaired innate immune function. J Leuko Biol. 2012; 91:829-838.

6. Liu PT, Stenger S, Li H, Wenzel L, Tan BH, Krutzik SR, Ochoa MT, Schauber J, Wu K, Meinken C and al. e. Tolllike receptor triggering of a vitamin D-mediated human antimicrobial response. Science. 2006; 311:1770-1773.

7. Cantorna MT. Why do T cells express the vitamin D receptor? Ann NY Acad Sci. 2011; 1217:77-82.

8. Penna G, Amuchastegui S, Giarratana N, Daniel KC, Vulcano M, Sozzani S and Adorini L. 1,25-dihydroxyvitamin D3 selectively modulates tolerogenic properties in myeloid but not plasmacytoid dendritic cells. J Immunol. 2007; 178:145-153.

9. Sloka S, Silva C, Wang J and Yong VW. Predominance of the th2 polarization by vitamin $\mathrm{D}$ through a stat6-dependent mechanism. J Neuroinflamm. 2011; 8:56.

10. Staeva-Vieira TP and Freedman LP. 1,25-dihydroxyvitamin D3 inhibits INF-gamma and IL-4 levels during in vitro polarization of primary murine CD4+ T cells. J Immunol. 2002; 168:1181-1189.

11. Prietl B, Treiber G, Pieber T and Amrein K. Vitamin D and immune function. Nutrients. 2013; 5:2502-2521.

12. Selvaraj $P$, Harishankar $M$ and Afsal K. Vitamin D: immunomodulation and tuberculosis treatment. Canadian $\mathrm{J}$ Physiol Pharmacol. 2015:1-8.

13. Kong J, Xu F, Qu J, Wang Y, Gao M, Yu H and Qian B. Genetic polymorphisms in the vitamin D pathway in relation to lung cancer risk and survival. Oncotarget. 2015; 6:2573-82. doi: 10.18632/oncotarget.2951.

14. Verone-Boyle A, Shoemaker S, Attwood K, Morrison C, Makowski A, Battaglia S and Hershberger P. Diet-derived 25-hydroxyvitamin D3 activates vitamin D receptor target gene expression and suppresses EGFR mutant non-small cell lung cancer growth in vitro and in vivo. Oncotarget. 2016; 7:995-1013. doi: 10.18632/oncotarget.6493.

15. Nemere I, Safford S, Rohe B, DeSouza M and FarachCarson M. Identification and characterization of 1,25 D3membrane-associated rapid response, steroid (1,25 D3MARRS) binding protein. J Steroid Biochem Molec Biol. 2004; 89:281-285.

16. Nemere I, Dormanen M, Hammond M, Okamura W and Norman A. Identification of a specific binding protein for 1 alpha,25-dihydroxyvitamin D3 in basal-lateral membranes of chick intestinal epithelium and relationship to transcaltachia. J Biol Chem. 1994; 269:23750-23756.

17. Fleet J. Rapid, membrane-initiated actions of 1,25 dihydroxyvitamin D: what are they and what do they mean? J Nutr. 2004; 134:3215-3218.

18. Wu W, Beilhartz G, Roy Y, Richard C, Curtin M, Browh L, Cadieux D, Coppolino M, Farach-Carson M, Nemere I and Meckling K. Nuclear translocation of the 1,25 D3-MARRS (membrane associated rapid response to steroids) receptor protein and NF-kappa B in differentiating NB4 leukemia cells. Exper Cell Res. 2010; 316:1101-1108.

19. Bettoun D, Buck D, Lu J, Khalifa B, Chin W and Nagpal S. Vitamin D receptor-ser/thr phosphatase-p70 s6 kinase complex and modulation of its enzymatic activities by the ligand. J Biol Chem. 2002; 277:24847-24850.

20. Richard C, Farach-Carson M, Rohe B, Nemere I and Meckling K. Involvement of 1,25 D3-MARRS (membrane associated, rapid response steroid-binding), a novel vitamin D receptor, in growth inhibition of breast cancer cells. Exper Cell Res. 2010; 316:695-703.

21. Miller RA. The aging immune system: subsets, signals, and survival. Aging (Milano). 1997; 9:23-24.

22. Miller RA. The aging immune system: primer and prospectus. Science. 1996; 273:70-74.

23. Ginaldi L, Loreto MF, Corsi MP, Modesti M and DeMartinis M. Immunosenescence and infectious diseases. 
Microbes Infect. 2001; 3:851-857.

24. Reber AJ, Chrikova T, Kim JH, Cao W, Biber R, Shay DK and Sambhara S. Immunosenescence and challenges of vaccination against influenza in the aging population. Aging Dis. 2012; 3:69-90.

25. van Duin D, Mohanty S, Thomas V, Ginter S, Montgomery RR, Fikrig E, Allore HG, Medzhitov R and Shaw AC. Ageassociated defect in human TLR-1/2 function. J Immunol. 2007; 178:970-975.

26. Sambhara S and McElhaney JE. Immunosenescence and influenza vaccine efficacy. Curr Topics Microbiol Immunol. 2009; 333:413-429.

27. Taylor AK, Cao W, Vora KP, De La Cruz J, Shieh WJ, Zaki SR, Katz JM, Sambhara S and Gangappa S. Protein energy malnutrition decreases immunity and increases susceptibility to influenza infection in mice. The Journal of infectious diseases. 2013; 207:501-510.

28. Cao W, Kim JH, Chrikova T, Reber AJ, Biber R, Shay DK and Sambhara S. Improving immunogenicity and effectiveness of influenza vaccine in older adults. Expert Rev Vaccines. 2011; 10:1529-1537.

29. Renshaw M, Rockwell J, Engleman C, Gewirtz A, Katz J and Sambhara S. Cutting edge: Impaired toll-like receptor expression and function in aging. J Immunol. 2002; 169:4697-701.

30. van Duin D and Shaw AC. Toll-like receptors in older adults. J Am Geriatr Soc. 2007; 55:1438-1444.

31. van Duin D, Allore HG, Mohanty S, Ginter S, Newman FK, Belshe RB, Medzhitov R and Shaw AC. Prevaccine determination of the expression of co-stimulatory B7 molecules in activated monocytes predicts influenza vaccine responses in young and older adults. J Infec Dis. 2007; 195:1590-1597.

32. Plowden J, Renshaw-Hoelscher M, Gangappa S, Engleman C, Katz JM and Sambhara S. Impaired antigen-induced CD8+ T cell clonal expansion in aging is due to defects in antigen presenting cell function. Cellular Immunol. 2004; 229:86-92.

33. Sambhara S, Kurich A, Miranda R, James O, Underdown B, Klein M, Tartaglia J and Burt D. Severe impairment of primary but not memory responses to influenza viral antigens in aged mice: co-stimulation in vivo partially reverses impaired primary immune responses. Cellular Immunol. 2001; 210:1-4.

34. Sambhara S, Kurichh A, Miranda R, Tamane A, Arpino R, James O, McGuinness U, Kandil A, Underdown B, Klein $\mathrm{M}$ and al. e. Enhanced immune responses and resistance against infection in aged mice conferred by flu-iscoms vaccine correlate with up-regulation of co-stimulatory molecule CD86. Vaccine. 1998; 16:1698-1704.

35. Kim TH, Lee B, Kwon E, Choi SJ, Lee YH, Song GG, Sohn J and Ji JD. Regulation of TREM-1 expression by 1,25-dihydroxyvitamin D3 in human monocytes/ macrophages. Immunol Lett. 2013; 154:80-85.

36. Yoneyama M and Fujita T. RNA recognition and signal transduction by RIG-I-like receptors. Immunol Rev. 2009; 227:54-65.

37. Saliba D, Elliott M, Rubenstein LZ, Solomon DH, Young RT, Kamberg CJ, Roth C, MacLean CH, Shekelle PG, Sloss EM and Wenger NS. The Vulnerable Elders Survey: a tool for identifying vulnerable older people in the community. $\mathrm{J}$ Am Geriatr Soc. 2001; 49:1691-1699.

38. Bischoff-Ferrari HA, Borchers M, Gudat F, Durmuller U, Stahelin HB and Dick W. Vitamin D receptor expression in human muscle tissue decreases with age. J Bone Miner Res. 2004; 19:265-269.

39. Blagosklonny M. How to save Medicare: the anti-aging remedy. Aging (Albany NY). 2012; 4:547-52. doi: 10.18632/aging. 100479.

40. Franceschi C, Bonafe M, Valensin S, Olivieri F, DeLuca M, Ottaviani E and DeBenedictis G. Inflamm-aging: an evolutionary perspective on immunosenescence. Ann NY Acad Sci. 2000; 908:244-254.

41. Wikby A, Ferguson F, Strindhall J, Forsey R, Fulop T, Hadrip SR, Thor Straten P and Johansson B. (2007). Immune risk phenotypes and associated parameters in very old humans: a review of findings in the Swedish Nona Longitudinal Study. Immunosenescence. (New York: Springer), pp. 1-14.

42. Ivashkiv L and Donlin L. Regulation of type I interferon responses. Nature Rev Immunol. 2014; 14:36-49.

43. Dusso AS, Brown AJ and Slatopolsky E. Vitamin D. Am J Physiol Renal Physiol. 2005; 289:F8-28.

44. Sundaram ME, Talbot HK, Zhu Y, Griffin MR, Spencer $\mathrm{S}$, Shay DK and Coleman LA. Vitamin D is not associated with serologic response to influenza vaccine in adults over 50 years old. Vaccine. 2013; 31:2057-2061.

45. Talbot HK, Coleman LA, Crimin K, Zhu Y, Rock MT, Meece J, Shay DK, Belongia EA and Griffin MR. Association between obesity and vulnerability and serologic response to influenza vaccination in older adults. Vaccine. 2012; 30:3937-3943.

46. Idler EL and Benyamini Y. Self-rated health and mortality: a review of twenty-seven community studies. J Health Soc Behav. 1997; 38:21-37.

47. Jylha M. What is self-rated health and why does it predict mortality? Towards a unified conceptual model. Soc Sci Med. 2009; 69:307-316.

48. Ross CA, Taylor CL, Yaktine AL and Del Valle HB. (2011). Dietary Reference Intakes for Calcium and Vitamin D. (Washington DC: National Academies of Science).

49. Livak KJ and Schmittgen TD. Analysis of relative gene expression data using real-time quantitative PCR and the 2(-delta delta $\mathrm{c}(\mathrm{t})$ ) method. Methods. 2001; 25:402-408. 